Volume 19 Number 2 December 2019.p. 506-527

https://doi.org/10.30603/au.v19i2. 1109

\title{
The Model of Reflective Moral Inquiry Design on the PAI Learning
}

\author{
Kasim Yahiji \& Nur Ainiyah \\ IAIN Sultan Amai Gorontalo \& Universitas Negeri Yogyakarta
}

\begin{abstract}
This article aims to explain the implementation of the model of reflective moral inquiry design in PAI learning. The reflective of the model of moral inquiry model design was developed based on reflective and self-analytical concepts with moral dilemmas approach that occur in daily life as a problem that must be solved by students through learning. This model is expected to make PAI learning more meaningful, students' knowledge about religious teachings can be a source of values and driving behavior for students in real life. But in fact, the implementation of PAI learning is more dominant in initiating the achievement of the knowledge aspect because the teacher's mindset is still using teacher-centered in implementing learning.
\end{abstract}

\section{Desain Model Pembelajaran Reflective Moral Inquiry pada Pembelajaran PAI}

\begin{abstract}
Abstrak
Artikel ini bertujuan memaparkan implementasi desain model reflective moral inquiry dalam pembelajaran PAI. desain model reflective moral inquiry dikembangkan berdasarkan konsep reflektif dan self-analitis" dengan pendekatan dilema moral yang terjadi dalam kehidupan sehari-hari sebagai suatu permasalahan yang harus diselesaikan peserta didik melalui pembelajaran. Model ini diharapkan dapat menjadikan pembelajaran PAI lebih bermakna, pengetahuan peserta didik tentang ajaran agama dapat menjadi sumber nilai dan penggerak perilaku bagi peserta didik dalam kehidupan nyata. Tetapi faktanya penyelenggaraan pembelajaran PAI selama ini masih lebih dominan memprakarsai pada pencapaian aspek pengetahuan saja, mindset guru dalam pelaksanaan pembelajaran juga masih bersifat teacher centered.
\end{abstract}

Kata Kunci: Pendidikan karakter, PAI, reflective moral inquiry

Author correspondence

Email: ainia82@gmail.com

_Available online at http://journal.iaingorontalo.ac.id/index.php/au/index 


\section{A. Pendahuluan}

Peserta didik mempelajari agama di sekolah sebagai sumber nilai dan penggerak perilaku mereka ${ }^{1}$. Oleh karena itu penting bagi guru untuk mempertimbangkan aspek kebermaknaan didalam pembelajaran, tujuannya agar peserta didik dapat mengimplementasikan pengetahuan yang ia miliki sebagai dasar dalam menjalani kehidupan di dunia nyata.

Pendidikan agama selama ini belum berfungsi secara optimal sebagai pendidikan budi pekerti bagi peserta didik. Hal ini dapat dilihat dari aspek penilaian yang dilakukan oleh guru masih mengedepankan pada aspek pengetahuan. Peneliti dalam hal ini melakukan wawancara terhadap guru PAI dan studi dokumentasi penilaian yang dimiliki oleh guru. Hasil survey tersebut menunjukkan jika guru aktif melakukakan penilaian pada aspek pengetahuan, sedangkan aspek afektif dan psikomotorik jarang atau bahkan tidak dilakukan secara kontinu, mereka beralasan terlalu banyak administrasi yang harus dikerjakan sehingga sulit untuk melakukan pengamatan secara kontinu dan terstruktur.

Ketidak konsistenan guru dalam melaksanakan pembelajaran sesuai dengan desain pembelajaran yang dibuat oleh guru sendiri menjadi salah satu faktor kelemahan pembelajaran PAI. Penulis melakukan survey dengan melakukan wawancara terhadap peserta didik dan guru, dapat disimpulkan jika selama ini guru lebih banyak menjelaskan materi, dan peserta didik lebih banyak mendengarkan padahal dari hasil studi dokumentasi terhadap rencana pelaksanaan pembelajaran (RPP); guru telah mendesain pembelajaran dengan berbagai pendekatan serta metode pembelajaran yang berorientasi pada student centererd. Fakta tersebut merupakan bukti jika mindset guru terhadap tujuan pembelajaran PAI lebih mementingkan pada pencapaian ranah pengetahuan.

Melibatkan peran serta peserta didik secara aktif dalam pembelajaran (pembelajaran aktif) merupakan cara yang paling efektif dalam pembelajaran PAI. Pembelajaran aktif memposisikan peserta didik sebagai subjek belajar. Hakikat belajar menurut pandangan psikologi modern merupakan peristiwa mental dan

\footnotetext{
${ }^{1}$ Mohammad Nuh, Menyemai Kreator Peradaban: Renungan Tentang Pendidikan, Agama, Dan Budaya, Cetakan I (Jakarta: Zaman, 2013), 76-77.
} 


\section{Desain Model Pembelajaran Reflective Moral Inquiry pada Pembelajaran PAI}

proses berpengalaman. Oleh karena itu dalam peristiwa belajar dituntut untuk melibatkan intelektual-emosional peserta didik melalui asimilasi dan akomodasi kognitif untuk mengembangkan pengetahuan, tindakan, serta pengalaman langsung dalam rangka membentuk ketrampilan (motorik, kognitif, dan sosial), penghayatan serta internalisasi nilai-nilai dalam pembentuk sikap²

Menghasilkan output yang mempunyai kompetensi dan mampu berkompetisi dalam dunia nyata adalah hakikat dari proses pendidikan. Kegiatan belajar mengajar sebagai proses yang sangat urgen dalam pendidikan memegang peranan kunci dalam mewujudkan hakikat pendidikan tersebut, oleh karena itu perlu merancang model pembelajaran yang memfasilitasi tumbuh kembang peserta didik secara maksimal, dengan memposisikan peserta didik sebagai subjek belajar yang mampu menemukan pengetahuannya sendiri melalui proses inkuiri, elaborasi, pemecahan masalah dan refleksi. Hal ini untuk merubah mindset jika belajar tidak hanya kegiatan mencatat dan menghafal materi pelajaran, tetapi belajar merupakan tempat mengekplorasi kemampuan peserta didik untuk tumbuh dan berkembang baik secara intelektual maupun emosionalnya.

Model pembelajaran yang berpusat pada guru (teacher centered) tidak memberikan kesempatan bagi peserta didik untuk aktif di dalam pembelajaran, sehingga pembelajaran yang tejadi hanya berupa pengalihan pengetahuan saja dan pembelajaran menjadi tidak bermakna. Akibatnya peserta didik tidak dapat mengimplementasikan pengetahuan yang ia miliki sebagai pondasi penggerak pikiran dan perilakunya dalam kehidupan sehari-hari.

Kebermaknaan di dalam pembelajaran PAI dapat di peroleh salah satunyan dengan mendesain model pembelajaran yang bersifat kontekstual. Pembelajaran PAI dengan pendekatan kontekstual dapat dilakukan dengan mengaitkan materi pembelajaran dengan konteks permasalahan moral yang terjadi dalam kehidupan sehari-hari. Guru mengajak peserta didik untuk terlibat aktif dalam proses menganalisis suatu permasalahan dan memecahkannya berdasarkan pengetahuan yang ia ketahui sebelumnya.

\footnotetext{
${ }^{2}$ Wina Sanjaya, Strategi Pembelajaran Berorientasi Standar Proses Pendidikan (Jakarta: Kencana, 2010), 12.
} 
Hal tersebut sejalan dengan konsep yang ditawarkan oleh Guirdi mengatakan jika pembelajaran yang berkaitan dengan penanaman karakter peserta didik akan efektif manakala diajarkan dengan proses yang "reflektif dan self-analitis", yaitu proses pembelajaran yang membimbing peserta didik untuk merefleksikan permasalahan-permasalahan moral dalam kehidupan sehai-hari, untuk kemudian menganalisisnya dan mencoba menyelesaikan permasalahan tersebut dengan pengetahuan yang telah dimiliki sebelumnya. Guidry menamakan model pembelajaran tersebut dengan refelctive moral inquiry.

Model reflective moral inquiry memandang peserta didik sebagai subjek didik, yang berarti jika di dalam proses belajar mengutamakan keterlibatan peserta didik secara aktif dalam pembelajaran, sedangkan posisi guru adalah sebagai fasilitator bagi peserta didik agar mudah dalam belajarnya. Belajar merupakan proses menemukan pengetahuan baru dengan cara yang empiris melalui proses inkuiri dan refleksi terhadap dilema moral yang terjadi dalam dunia nyata.

Berdasarkan karakteristik tujuan Pendidikan Agama Islam (PAI) yang berorientasi pada penanaman budi pekerti, sangat efektif jika dirancang dengan model reflective moral inquiry. Tujuan dari pengembangan desain model reflective moral inquiry dalam pembelajaran PAI adalah agar nilai-nilai agama yang telah dipahami peserta didik menjadi landasan dalam berpikir dan penggerak dalam berperilaku dalam kehidupan sehari-hari. Model reflective moral inquiry dalam pembelajaran Pendidikan Agama Islam diterapkan dengan cara mengajarkan nilainilai akhlak kepada peserta didik dengan merefleksikan berbagai permasalahan moral yang dilematis dalam kehidupan sehari-hari, kemudian peserta didik mengeksplorasi berbagai alternatif pemecahan masalah sesuai dengan pengetahuan yang telah dimiliki. Model tersebut diharapakan dapat meningkatkan partisipasi aktif peserta didik dan kebermaknaan dalam pembelajaran.

\section{B. Konsep Dasar Model Reflective Moral Inquiry}

\section{Proses reflective thinking dalam pembelajaran}

Model reflective moral inquiry didasarkan pada konsep berpikir reflektif (reflective thinking) dan model inkuiri. Proses reflective thinking adalah 


\section{Desain Model Pembelajaran Reflective Moral Inquiry pada Pembelajaran PAI}

keyakinan yang dicapai dengan membandingkan teori dengan fakta yang telah diketahui dengan pertimbangan yang teliti dan hati-hati terhadap keyakinan atau bentuk pengetahuan yang diharapkan berdasarkan alasan yang mendukungnya ${ }^{3}$ proses refleksi melibatkan dua hal (a) karena adanya kebingungan dan sikap ragu-ragu dari seseorang; (b) tindakan pencarian atau penyelidikan (inkuiri) yang bertujuan mencari fakta untuk menguatkan atau bahkan sebaliknya menghapus hipotesis yang telah dibuat ${ }^{4}$.

Reflective thinking merupakan landasan dasar dalam mengembangkan konsep belajar berorientasi peserta didik yang bertujuan meningkatkan keterampilan berpikir kritis serta kemampuan merefleksikan kebermaknaan dalam pembelajaran. Konsep reflective thinking melatih peserta didik untuk berpikir sistematis dan empiris dalam memperoleh pengetahuan baru.

Rodgers mengatakan jika reflective thinking merupakan sebuah alat atau kendaraan yang digunakan dalam mentransformasi raw experience (pengalaman mentah) menjadi Meaning filled (pengalaman bermakna) berdasarkan pada pengalaman dan teori yang telah dipelajari sebelumnya. Proses refleksi ini merupakan proses yang sistematis yang mencakup proses observasi dan deskripsi rinci tentang sebuah pengalaman dengan melibatkan interaksi antara diri sendiri, orang lain dan lingkungannya. Proses reflective thinking melibatkan disiplin kognitif dan disiplin emosional seseorang. Proses refleksi "menunjukkan praktik penyelidikan atau inkuiri yang berkaitan dengan fenomena masa lalu, terkini atau masa depan, seperti kebijakan, tindakan, proses dan kejadian. Refleksi berarti melibatkan proses membandingkan, mempertimbangkan alternatif, melihat hal-hal dari berbagai perspektif, dan menggambarkan kesimpulan ${ }^{5}$. Reflective thinking melibatkan

\footnotetext{
${ }^{3}$ John Dewey, How We Think (Mineola, N.Y: Dover Publications, 1997), 3.

${ }^{4}$ Dewey, 9.

${ }^{5}$ Silvia Jordan, Martin Messner, and Albrecht Becker, "Reflection and Mindfulness in Organizations: Rationales and Possibilities for Integration," Management Learning 40, no. 4 (September 2009): 466, https://doi.org/10.1177/1350507609339687.
} 
kemampuan untuk membuat pilihan rasional dan Untuk memikul tanggung jawab atas pilihan mereka ${ }^{6}$.

Reflective thinking merupakan bagian yang sangat penting dalam pembelajaran kontekstual. Reflective thinking didefinisikan sebagai cara berpikir tentang apa yang baru dipelajari atau berpikir ke belakang tentang apa yang sudah dilakukan pada masa lalu. Fungsi dari reflective thinking adalah untuk mengevaluasi pengetahuan atau pengalaman lama dengan pengetahuan atau pengalaman yang baru 7 .

Terdapat empat kriteria proses pembelajaran berdasarkan reflective thinking yaitu:

1) Refleksi adalah proses pemberian makna berdasarkan pengalaman peserta didik dan mengkonstruksikannya dengan pengetahuan yang lain untuk mendapatkan pemahaman yang lebih mendalam

2) Refleksi adalah cara berpikir yang sistematis, ketat, dan disiplin, dengan berdasarkan penyelidikan ilmiah.

3) Refleksi perlu dalam konteks kehidupan sosial, hal ini berkaitan dengan interaksi sosial yang terjadi dimasyarakat

4) Refleksi membutuhkan sikap yang meningkatkan pertumbuhan pribadi dan intelektual diri sendiri dan orang lain. ${ }^{8}$

Konsep pembelajaran berbasis reflective thinking menganggap belajar adalah proses yang menjembatani sikap keingin tahuan peserta didik terhadap berbagai macam persoalan yang mereka lihat atau bahkan mereka alami untuk dapat dipecahkan dalam proses pembelajaran dengan cara dan metode yang ilmiah. Oleh karena itu penilaian terhadap "Proses belajar" dianggap sama pentingnya dengan penilaian hasil belajar.

\footnotetext{
${ }^{6}$ Dorene Doerre Ross, "First Steps in Developing A Reflective Approach," Journal of Teacher Education 40, no. 2 (March 1989): 22, https://doi.org/10.1177/002248718904000205.

${ }^{7}$ Suyanto and Asep Jihad, Menjadi Guru Profesional Strategi Meningkatkan Dan Kualitas Guru Di Ers Global (Erlangga, 2013), 169.

${ }^{8}$ Carol Rodgers, "Defining Reflection: Another Look at John Dewey and Reflective Thinking," Teachers College, Columbia University 104 (2002): 845.
} 


\section{Desain Model Pembelajaran Reflective Moral Inquiry pada Pembelajaran PAI}

Untuk mendorong kemampuan reflective thinking pada peserta didik, maka seharusnya guru mengajar dengan sepenuh hati dengan selalu menjaga pola pikir, sikap dan perilakunya. Guru selalu belajar bagaimana memahami proses pengajaran mereka dan selalu mempunyai keinginan untuk memperbaiki bagaimana melakukan pembelajaran yang bermakna dan dapat berpengaruh dalam kehidupan peserta $\operatorname{didik}^{9}$ Oleh karena itu ada beberapa hal yang perlu diperhatikan oleh guru. Pertama, dalam pembelajaran di kelas. Muatan pernbelajaran perlu secara langsung dikaitkan dengan realitas kehidupan, sehingga proses reflective thinking pada diri peserta didik dapat langsung terkait dengan pengalaman pribadinya. Kedua, sebelum guru menyampaikan materi baru, Ia perlu mengulang pengetahuan-pengetahuan sebelumnya agar peserta didik diingatkan tentang adanya kaitan pengetahuan itu dengan pengetahuan baru. Hal ini diharapkan dapat membantu proses reflective thinking pada diri peserta didik, sekaligus dapat mengurangi dominasi pengetahuan yang pasif dan kurang fungsional ${ }^{10}$

\section{Prosen inkuiri dalam pembelajaran}

Inkuiri adalah sebuah pendekatan pembelajaran yang melibatkan peserta didik dalam menemukan dan menggunakan berbagai sumber informasi dan gagasan untuk meningkatkan pemahaman mereka tentang area spesifik kurikulum. Ini bukan sekadar menjawab pertanyaan dan mendapatkan jawaban yang benar. Pembelajaran inkuiri melibatkan minat peserta didik, Dan menantang peserta didik untuk menghubungkan dunia mereka dengan kurikulum. Penyelidikan tidak berdiri sendiri namun didasarkan pada isi kurikulum yang memotivasi peserta didik untuk mempertanyakan, mengeksplorasi, dan merumuskan gagasan baru. Meski sering dianggap sebagai inkuiri individu. Proses Penyelidikan juga dapat didesain dengan melibatkan komunitas peserta didik dalam interaksi sosial dimana masingmasing dapat belajar dari yang lain. Penyelidikan adalah cara belajar yang

9 Zeichner, Kenneth M., and Daniel Patrick Liston. Reflective Teaching: An Introduction. Reflective Teaching and the Social Conditions of Schooling. Mahwah, N.J: L. Erlbaum Associates, 1996.p.5-6 10 Suyanto, and Asep Jihad. Menjadi Guru Profesional Strategi Meningkatkan Dan Kualitas Guru Di Ers Global. Erlangga, 2013. 
mempersiapkan peserta didik untuk berpikir sendiri. Membuat keputusan bijaksana, mengembangkan bidang keahlian, dan belajar sepanjang hidup mereka ${ }^{11}$

Desain pembelajaran inkuiri dipengaruhi oleh aliran belajar kognitif, aliran ini menganggap jika belajar pada hakikatnya adalah proses mental dan proses berpikir dengan memanfaatkan segala potensi yang dimiliki setiap individu secara optimal ${ }^{12}$. Model pembelajaran inkuiri didefinisikan sebagai rangkaian kegiatan pembelajaran yang menekankan pada proses berpikir secara kritis dan analitis untuk mencari dan menemukan sendiri jawaban dari suatu masalah yang dipertanyakan.

Ada beberapa hal yang menjadi ciri utama strategi pembelajaran inkuiri yaitu:

1) Menempatkan peserta didik sebagai subjek belajar, guru mendorong peserta didik untuk aktif dalam pembelajaran, mengajak peserta didik untuk mencari serta menemukan sendiri inti dari pembelajaran.

2) Aktivitas belajar bersifat student centered, sehingga peran guru adalah sebagai fasilitator dalam pembelajaran yang mengarahkan peserta didik untuk mencari serta menemukan inti pembelajaran melalui berbagai strategi pembelajaran yang mendukung proses inkuiritersebut. Hal ini bertujuan untuk meningkatkan sikap keyakinan diri peserta didik (self Efficacy).

3) Tujuan pembelajaran adalah mengembangkan seluruh potensi yang dimiliki oleh peserta didik, oleh karenanya peserta didik dibiasakan untuk berpikir sistematis, logis dan kritis. Pola berpikir seperti ini akan mengembangkan sikap mental serta intelektual peserta didik secara seimbang, sehingga kualitas proses merupakan hal yang sangat penting dari model pembelajaran reflektif inkuiri ${ }^{13}$.

${ }^{11}$ Carol Collier Kuhlthau, Leslie K. Maniotes, and Ann K. Caspari, Guided Inquiry: Learning in the 21st Century (Westport, Conn: Libraries Unlimited, 2007), 2.

${ }^{12}$ Sanjaya, Strategi Pembelajaran Berorientasi Standar Proses Pendidikan, 195.

${ }^{13}$ Sanjaya, 196-97. 


\section{Desain Model Pembelajaran Reflective Moral Inquiry pada Pembelajaran PAI}

Langkah-langkah dalam model pembelajaran inquiry melibatkan peserta didik secara aktif dalam pembelajaran yang terdiri dari:

1) keterlibatan (engage), pada tahap ini diawali dengan keterlibatan peserta didik dalam menemukan dan mengidentifikasi tugas pembelajaran. Dalam tahap ini tugas guru adalah menarik perhatian peserta didik dan merangsang pemikiran mereka, dengan memberikan Pertanyaan yang berkaitan dengan pengalaman belajar peserta didik dimasa lalu dan pengetahuan saat ini. Tahap ini juga merupakan tahap pendefinisian terhadap permasalahan.

2) menjelajahi (explore). Peserta didik secara langsung terlibat dengan fenomena dan materi. Mereka mengembangkan landasan pengalaman dengan fenomena tersebut. Peserta didik mengidentifikasi dan mengembangkan konsep, proses, dan keterampilan. Mereka secara aktif mengeksplorasi lingkungan mereka atau memanipulasi materi.

3) Jelaskan (explain). Peserta didik dilibatkan dalam kegiatan analisis terhadap hasil eksplorasi mereka. Mereka menempatkan pengalaman abstrak ke dalam bentuk yang communicable (dapat ditransmisikan). Peserta didik memiliki kesempatan menampilkan secara verbalisasi pemahaman konseptual mereka atau untuk menunjukkan keterampilan atau perilaku baru. Pemahaman peserta didik diklarifikasi dan dimodifikasi karena aktivitas reflective.

4) Menguraikan (elaborate). Peserta didik memperluas konsep yang telah mereka pelajari, membuat koneksi ke konsep terkait lainnya, dan menerapkan pemahaman mereka kepada dunia di sekitar mereka, Hubungan ini sering mengarah pada penyelidikan lebih lanjut dan pemahaman baru.

5) Evaluasi (evaluate). Guru menentukan apakah peserta didik telah mencapai pemahaman tentang konsep dan pengetahuan. Evaluasi dan 
penilaian dapat terjadi pada semua point sepanjang kontinum proses pembelajaran ${ }^{14}$.

Konsep pembelajaran reflective thinking dan inkuiri merupakan konsep yang saling beriringan dan menjadi satu kesatuan sebagai sebuah pendekatan dalam pembelajaran. Keduanya memandang jika belajar merupakan proses berpikir empiris. Peserta didik dianggap sebagai subjek belajar, sedangkan fungsi guru adalah sebagai fasilitator dalam belajar; mengarahkan, memberi rangsangan serta memotivasi peserta didik dalam proses pembelajaran. Maka dalam hal ini fungsi belajar menjadi sarana bagi peserta didik untuk mengembangkan segala potensi yang dimilikinya baik secara intelektual maupun emosional. Sebagai sebuah model, pendekatan inkuiri berimplikasi menciptakan pembelajaran yang bermakna.

\section{Penekatan kontekstual dalam pembelajaran}

Pendekatan Pembelajaran Kontekstual adalah suatu proses pendidikan yang holistik dan bertujuan memotivasi peserta didik untuk memahami makna materi pelajaran yang dipelajarinya dengan mengkaitkan materi tersebut dengan konteks kehidupan mereka sehari-hari (konteks pribadi, sosial, dan kultural) sehingga peserta didik memiliki pengetahuan atau keterampilan yang dapat diterapkan secara fleksibel dari satu permasalahan ke permasalahan lainnya dan dan satu konteks ke konteks lainnya.

Melalui pendekatan kontekstual, mengajar bukan transformasi pengetahuan dari guru kepada peserta didik dengan menghafal sejumlah konsep-konsep yang sepertinya terlepas dari kehidupan nyata, akan tetapi lebih ditekankan pada upaya memfasilitasi peserta didik untuk mencari kemampuan untuk bisa hidup dari apa yang dipelajarinya. Oleh karena itu dalam pendekatan kontekstual guru menghadirkan dunia nyata kedalam kelas dan mendorong peserta didik membuat hubungan antara pengetahuan yang dimilikinya dengan penerapannya dalam kehidupan mereka sehari-hari, sementara peserta didik memperoleh pengetahuan dan ketrampilan dari konteks yang terbatas, sedikit demi sedikit, dan dari proses mengkonstruksi

${ }^{14}$ Kenneth D. Moore, Effective Instructional Strategies: From Theory to Practice, 2nd ed (Thousand Oaks, Calif: Sage Publications, 2009), 184. 


\section{Desain Model Pembelajaran Reflective Moral Inquiry pada Pembelajaran PAI}

sendiri, sebagai bekal untuk memecahkan masalah dalam kehidupannya sebagai anggota masyarakat (permendikbud. No 28 tahun 2014: 16).

Kenneth mendefinisikan pembelajaran kontekstual sebagai suatu pembelajaran yang memungkinkan terjadinya proses belajar dan didalamnya peserta didik dimungkinkan menerapkan pemahaman serta kemampuan akademik mereka dalam berbagai variasi konteks, di dalam maupun luar kelas, untuk menyelesaikan permasalahan nyata atau yang disimulasikan baik secara sendiri-sendiri maupun berkelompok ${ }^{15}$.

Pendekatan pembelajaran kontekstual setidaknya terdiri dari tiga prinsip dasar yaitu:

1) Pembelajaran kontekstual menekankan pada pengalaman secara langsung dalam pembelajaran

2) Mendorong peserta didik untuk menemukan hubungan antara materi yang dipelajari dengan situasi kehidupan nyata

3) Mendorong peserta didik untuk dapat menerapkannya dalam kehidupan nyata 16

Pembelajaran kontekstual melibatkan peserta didik dalam kegiatan yang signifikan membantu mereka menghubungkan studi akademik ke konteks mereka dalam situasi kehidupan nyata. Dengan membuat koneksi ini, peserta didik melihat kebermakna dalam pembelajaran. Peserta didik dapat merumuskan proyek atau mengidentifikasi masalah yang menarik, membuat pilihan dan menerima tanggung jawab, mencari informasi dan mencapai kesimpulan, mereka secara aktif memilih, memesan, mengatur, menyentuh, merencanakan, menyelidiki, mempertanyakan, dan membuat keputusan untuk mencapai tujuan, mereka menghubungkan konten akademik ke konteks situasi kehidupan, dan dengan cara tersubt maka akan ditemukan kebermaknaan, sehingga inti dari pembelajaran kontekstual adalah "ditemukan kebermaknaan" dalam pembelajaran

15 Kenneth, Howey R. Contextual Teaching and Learning : Preparing Teacher to Enhance Student Success in and beyond School. washington DC: ERIC Clearinghouse on Teaching and Teacher Education American Association off College for Teacher Education., 2001.

${ }^{16}$ Sanjaya, Strategi Pembelajaran Berorientasi Standar Proses Pendidikan, 255. 
Berdasarkan pada prinsip pendekatan pembelajaran kontekstual di atas, maka penulis merancang dilema moral yang terjadi dalam masyarakat sebagai salah satu pendekatan yang digunakan dalam model pembelajaran PAI. Tujuan dari pendekatan ini adalah agar peserta didik dapat merefleksikan serta mengimplementasikan nilai-nilai agama yang ia pelajari dalam kehidupan sehari-hari.

Dilema moral sebagai sebuah pendekatan diimplementasikan dalam setiap topik pembelajaran. Setiap sesi pembelajaran guru mengaitkan topik pembelajaran dengan dilema moral yang sering terjadi dimasyarakat sebagai sebuah permasalahan yang harus diselesaikan oleh peserta didik.

\section{Sintak Model Pembelajaran Reflective Moral Inquiry}

Model reflective moral inquiry merupakan model pembelajaran karakter yang dikenalkan oleh Guidry dengan konsep "reflektif dan self-analitis". Secara praktis implementasi dari model ini adalah dengan mengkonfrontasikan peserta didik antara pengalaman historis dengan problem empiris di masyarakat yang menimbulkan dilema moral. Model ini dirancang dengan menerapkan pendekatan pedagogi yang memungkinkan peserta didik untuk mengeksplorasi moral dan dilema etika dalam konteks konten studi sosial. Model ini menggunakan pendekatan pengajaran yang menarik dan bermakna, mengintegrasikan pendidikan akademik dan moral serta mendorong kesadaran global dan budaya di antara peserta didik.

Ada enam langkah dalam model reflective moral inquiry yang dikembangkan oleh ${ }^{17}$ yaitu:

a. Step I: (introduction of the problem) Mengenalkan kepada peserta didik terhadap dilema moral atau etika atau masalah yang berakar pada konten studi sosial yang terjadi dilingkungan peserta didik.

b. Step II: (hypothesis formation) Mengajak peserta didik untuk membentuk hipotesis yang mengarah pada pemecahan masalah terhadap dilema moral yang ditemukan.

\footnotetext{
${ }^{17}$ Allen O. Guidry, "Character Education Through a Reflective Moral Inquiry: A Revised Model That Answers Old Questions," Journal of Curriculum and Instruction 2, no. 1 (January 2, 2008): 26, https://doi.org/10.3776/joci.2008.v2n1p21-37.
} 


\section{Desain Model Pembelajaran Reflective Moral Inquiry pada Pembelajaran PAI}

c. Step III: (exploration and information of evidence) Melibatkan peserta didik dalam proses eksplorasi terhadap bukti-bukti berdasarkan pengetahuan dan teori yang dimiliki untuk kemudian membuktikan hipotesis yang mereka rumuskan.

d. Step IV: (translation and interpretation of evidence) Mengharuskan peserta didik untuk memahami dan menafsirkan bukti yang terkumpul untuk menjawab hipotesis.

e. Step V: (evaluation of hypothesis) Memberikan kesempatan kepada peserta didik untuk merefleksikan bukti-bukti yang terkumpul dengan fenomena sosial yang ada di sekeliling mereka. Memberikan alternatif pemecahan masalah sesuai dengan pengetahuan yang telah dimiliki sebelumnya.

f. Step VI: (formation of principle) Membuat kesimpulan terhadap hasil analisis dan proses refleksi dalam bentuk hasil laporan tertulis secara sederhana

Keenam langkah ini mendorong peserta didik untuk berpikir sistematis dalam memecahkan berbagai dilema moral dalam kehidupan nyata. Langkah ini memberikan kesempatan kepada peserta didik untuk mengkonstruk pengetahuan tentang materi yang sedang dipelajari melalui proses inkuiri dan refleksi. Guidry (2008:26) mengatakan bersamaan dengan hal tersebut guru juga dapat mengarahkan peserta didik untuk membangun prinsip-prinsip moral (pedoman moral atau peraturan) dengan menggunakan pedoman dan kriteria yang mereka buat dan bangun selama diskusi kelas. Dalam struktur kelompok diskusi, peserta didik terlibat dalam percakapan tentang implikasi tindakan seseorang terhadap orang lain. Pertukaran gagasan ini menghasilkan perkembangan prinsip moral yang dapat diterima secara universal.

\section{Karakteristik Pendidikan Agama Islam (PAI)}

PAI dalam konteks kurikulum nasional menjadi salah satu mata pelajaran utama yang bertujuan untuk menanamkan budi pekerti bagi peserta didik. Nilainilai agama yang diajarkan melalui PAI diharapkan dapat menjadi dasar dalam berperilaku dalam kehidupan sehari-hari. Berdasarkan hal tersebut maka perlu mengimplementasikan desain model pembelajaran yang bersifat kontekstual pada PAI. Pembelajaran kontekstual ini dimaksudkan untuk membantu peserta didik 
memahami makna materi dengan mengaitkan topik pelajaran dengan konteks kehidupan sehari-hari (pribadi, sosial dan budaya), sehingga peserta didik memiliki pengetahuan yang secara fleksibel dapat diterapkan dari satu permasalahan atau konteks ke permasalahan lainnya. ${ }^{18}$, oleh karena itu selain PAI menjadi kajian tersendiri dalam sebuah mata pelajaran, maka pembelajaran PAI juga terintegrasi dalam semua mata pelajaran yang tercantum dalam kompetensi inti dalam setiap mata pelajaran. Adapun Karakteristik PAI adalah sebagai berikut:

a. Objek kajian PAI adalah manusia bukan benda mati, baik yang ada dialam maupun dalam diri manusia, yang berkaitan dengan inner side, mental life, dan mind affected world .

b. PAI melihat subject matter dengan empati intelectual, tidak menjadikannya semata-mata menjadi objek.

c. PAI tidak pernah mengklaim sebagai ilmu yang value free sepenuhnya, sebab setiap pemaknaan selalu melibatkan pemaknanya, meskipun demikian PAI harus mematuhi sumber dan harus tuntas mencari sumber yang valid dan tidak boleh menyembunyikan keterangan apapun.

d. Manusia mempunyai free will dan kesadaran, karena itulah manusia bukan benda yang sudah ditentukan oleh hukum-hukum kausalitas.

e. Validitas PAI terletak dalam keabsahan sumbernya. Sumber PAI adalah norma dan nilai yang berupa aturan-aturan hukum ${ }^{19}$.

Karakteristik PAI diatas memandang bahwa objek kajian PAI adalah manusia sebagai makhluk yang mempunyai daya fikir dan terus mengalami perubahan dipandang dari diri manusia itu sendiri, dari segi mentalnya dan dampak dari kehidupannya. Objek kajian PAI disandarkan pada Al quran dan hadits sebagai sumber dari ajaran Islam.

Dalam konteks kurikulum 2013 karakteristik mata pelajaran PAI dan Budi Pekerti lebih melihat subject matter PAI berfungsi sebagai bagian dari pembentukan akhlak atau kepribadian peserta didik. Dalam lampiran

\footnotetext{
${ }^{18}$ Bermawy Munthe, "Desain Strategi Pembelajaran Pendidikan Agama Islam DI Sekolah,” El-Wasathiya: Jurnal Studi Agama; Vol 1 No 1 (2013), June 13, 2013, 4, http://ejournal.kopertais4.or.id/mataraman/index.php/washatiya/article/view/1660.

${ }^{19}$ Bermawy Munthe, "Desain Strategi Pembelajaran PAI Di Sekolah" 1 (20`13): 2-3.
} 


\section{Desain Model Pembelajaran Reflective Moral Inquiry pada Pembelajaran PAI}

permendikbud No 58 tahun 2014 tentang kurikulum sekolah menengah pertama disebutkan beberapa karakteristik PAI sebagai berikut:

a. PAI dan Budi Pekerti merupakan mata pelajaran yang dikembangkan dari materi pokok PAI (al-Qur'an dan Hadis, aqidah, akhlak, fiqih dan sejarah peradaban Islam).

b. Ditinjau dari segi muatan pendidikannya, PAI dan Budi Pekerti merupakan mata pelajaran pokok yang menjadi satu komponen yang tidak dapat dipisahkan dengan mata pelajaran lain yang bertujuan untuk pengembangan moral dan kepribadian peserta didik. Maka, semua mata pelajaran yang memiliki tujuan tersebut harus seiring dan sejalan dengan tujuan yang ingin dicapai oleh mata pelajaran PAI dan Budi Pekerti.

c. Diberikannya mata pelajaran PAI dan Budi Pekerti bertujuan untuk terbentuknya peserta didik yang beriman dan bertakwa kepada Allah Swt., berbudi pekerti yang luhur (berakhlak yang mulia), dan memiliki pengetahuan yang cukup tentang Islam, terutama sumber ajaran dan sendisendi Islam lainnya, sehingga dapat dijadikan bekal untuk memelajari berbagai bidang ilmu atau mata pelajaran tanpa harus terbawa oleh pengaruh-pengaruh negatif yang mungkin ditimbulkan oleh ilmu dan mata pelajaran tersebut.

d. PAI dan Budi Pekerti adalah mata pelajaran yang tidak hanya mengantarkan peserta didik dapat menguasai berbagai kajian keIslaman, tetapi PAI lebih menekankan bagaimana peserta didik mampu menguasai kajian keIslaman tersebut sekaligus dapat mengamalkannya dalam kehidupan sehari-hari di tengah-tengah masyarakat. Dengan demikian, PAI dan Budi Pekerti tidak hanya menekankan pada aspek kognitif saja, tetapi yang lebih penting adalah pada aspek afektif dan psikomotornya.

e. Secara umum mata pelajaran PAI dan Budi Pekerti didasarkan pada ketentuan-ketentuan yang ada pada dua sumber pokok ajaran Islam, yaitu al-Qur'an dan Hadis Nabi Muhammad saw., juga melalui metode ijtihad (dalil aqli), para ulama dapat mengembangkannya dengan lebih rinci dan mendetail dalam kajian fiqih dan hasil-hasil ijtihad lainnya. 
f. Tujuan akhir dari mata pelajaran PAI dan Budi Pekerti adalah terbentuknya peserta didik yang memiliki akhlak yang mulia (budi pekerti yang luhur), yang merupakan misi utama diutusnya Nabi Muhammad saw di dunia. Hal ini tidak berarti bahwa pendidikan Islam tidak memerhatikan pendidikan jasmani, akal, ilmu, ataupun segi-segi praktis lainnya, tetapi maksudnya adalah bahwa pendidikan Islam memerhatikan segi-segi pendidikan akhlak seperti juga segi-segi lainnya.

Berdasarkan karakteristik dari mata pelajaran PAI diatas, megindikasikan jika pencapaian kompetensi PAI tidak hanya sampai pada pengalaman mengetahui saja tetapi bagaimanakah pengamalan dari nilai-nilai agama menjadi hal yang sangat urgen, oleh karena itu dibutuhkan strategi pembelajaran yang tidak hanya menstransfer pengetahuan saja, tetapi bagaimana membangkitkan kegiatan belajar ke dalam aktivitas doing (melakukan) sampai menjadi being (terbiasa). Hal tersebut membutuhkan desain model pembelajaran yang melibatkan peserta didik secara aktif dalam pembelajaran (student centered). Model pembelajaran yang bersifat student centered merupakan salah satu jawaban yang menawarkan bagaimana keaktifan peserta didik dalam pembelajaran dapat melatih serta meningkatkan kreatifitas serta motivasi peserta didik dalam pembelajaran. Maka didalam lampiran permendikbud No 58 tahun 2014 tentang kurikulum 2013 sekolah menengah pertama menyebutkan jika strategi implementasi PAI dilakukan dengan memperkuat pendekatan ilmiah (scientific), dan tematik internal (dalam suatu mata pelajaran) dengan menerapkan pembelajaran berbasis penyingkapan/penelitian (discovery/inquiry learning). Untuk mendorong kemampuan peserta didik menghasilkan karya kontekstual, baik individual maupun kelompok maka sangat disarankan menggunakan pendekatan pembelajaran yang menghasilkan karya (project based learning), dan berbasis pemecahan masalah (problem based learning).

Marylin lewis mengatakan jika pembelajaran berbasis student centered berprinsip pada "start with what student know, and move on from there" ${ }^{20}$. Maka Guru harus mampu menjadi fasilitator dalam proses belajar bagi peserta didik,

\footnotetext{
${ }^{20}$ Marilyn Lewis and Hayo Reinders, Using Student-Centered Methods with TeacherCentered Students (Pippin Publishing Corporation, 2007), 12.
} 


\section{Desain Model Pembelajaran Reflective Moral Inquiry pada Pembelajaran PAI}

merancang desain model pembelajaran yang tepat adalah hal yang wajib dilakukan oleh guru agar dapat memfasilitasi tumbuh kembang serta kreatifitas peserta didik dengan baik, guru dapat memberikan pembelajaran yang bersifat kontekstual agar peserta didik dapat memberikan makna terhadap apa yang ia pelajari, peserta didik dilatih untuk menganalisis persoalan-persoalan yang terjadi dilingkungannya serta bagaimana mengatasinya. Hal ini bertujuan agar konsep yang telah peserta didik ketahui (aspek kognitif) dapat diterapkan dalam konteks kehidupan peserta didik sehari-hari.

Model pembelajaran PAI yang bersifat kontekstual menjadi alternatif pilihan yang dianggap paling tepat. Model pembelajaran ini akan lebih menyentuh aspek afeksi anak didik dan memotivasinya untuk dapat mengaktualisasikan nilainilai atau konsep-konsep yang didapat dari materi-materi PAI 21.

Dalam naskah akademik kajian kebijakan kurikulum PAI tahun 2007 direkomendasikan jika implementasi PAI seharusnya memperhatikan hal-hal sebagai berikut:

a. Pengembangan materi dan pembelajaran yang bersifat utuh ( holistik )

b. Mengedepankan nilai-nilai universal

c. Terintegrasi dengan ilmu-ilmu pengetahuan lainnya

d. Memperhatikan keragaman nilai-nilai budaya masyarakat Indonesia

e. Implementasi pendidikan agama menjadi tanggung jawab semua pihak (Dinas Pendidikan, Departemen Agama, Pengawas, Kepala Sekolah, Semua Guru Mata Pelajaran, Komite Sekolah,Yayasan Pengelola Pendidikan, orang tua peserta didik dan masyarakat. )

f. Implementasi pendidikan agama mengedepankan pengamalan dalam kehidupan sehari-hari.

g. Pembelajaran pendidikan agama mengedepankan persamaan dan menghargai perbedaan.

h. Dalam setiap satuan jenjang pendidikan, mengedepankan kehidupan beragama (religius ).

\footnotetext{
${ }^{21}$ Muhammad Iwan Abdi, "Contextual Teaching and Learning (CTL) Dalam Pembelajaran PAI," Dinamika Ilmu 11, no. 1 (June 15, 2011): 9, https://doi.org/10.21093/di.v11i1.49.
} 
Pengembangan model pembelajaran PAI dengan Pendekatan kontekstual berdasarkan konsep di atas dapat didesain dengan memperkuat unsur ilmiah (scientific) dengan mengimplementasikan discovery learning, problem based learning dan project based learning.

\section{Implementasi Model Reflctive Moral Inquiry dalam Pembelajaran PAI}

Berdasarkan pada kajian teori diatas peneliti tertarik untuk megembangkan model reflective moral inkuiry sebagai salah satu alternatif model desain pembelajaran PAI. Model ini dikembangkan dengan tujuan untuk menciptakan pembelajaran bermakna melalui konsep berpikir ilmiah. Model ini diharapkan tidak hanya berpengaruh pada hasil belajar yang bersifat akademik saja, tetapi dapat mengembangkan berbagai macam soft skill bagi peserta didik.

Akhlak atau budi pekerti sebagai tujuan utama dari pembelajaran PAI menuntut guru untuk mampu merefleksikan kajian materi pembelajaran dengan permasalahan dalam kehidupan nyata agar pembelajaran menjadi bermakna. Kebermaknaan pembelajaran dimaksudkan agar peserta didik memiliki kesadaran akan pentingnya memahami nilai-nilai agama sebagai pedoman dalam berperilaku.

Implementasi desain model reflective moral inquiry dalam pembelajaran PAI adalah sebagai berikut:

\section{a. Step 1: Mengenalkan Permasalahan}

Guru memulai pembelajaran dengan mengenalkan kepada peserta didik terhadap dilema moral atau etika masalah yang berakar pada konten studi sosial sesuai dengan topik yang sedang dibahas. Pada tahap ini sebaiknya guru memberikan tugas kepada peserta didik berupa penyelesaian problem sosial yang terjadi di masyarakat. Misalnya sedang membahas tentang materi empati, berkaitan dengan hal tersebut guru dapat menyajikan dalam bentuk gambar atau cerita tentang kejadian bencana alam, kemiskinan dan permasalahan lain yang dapat dikaitkan dengan topik empati.

\section{b. Step 2: Membentuk Hipotesis}

Guru membimbing peserta didik untuk membentuk hipotesis yang mengarah pada pemecahan masalah terhadap dilema moral yang ditemukan, dengan cara bagaimana respon atau tanggapan peserta didik terhadap gambar 


\section{Desain Model Pembelajaran Reflective Moral Inquiry pada Pembelajaran PAI}

atau cerita yang disajikan dan langkah apa yang akan dilakukan untuk menyelesaikan permasalahan tersebut.

\section{c. Step 3: Mengekplorasi Informasi untuk Membuktikan Hipotesis}

Melibatkan peserta didik dalam proses eksplorasi terhadap bukti-bukti berdasarkan pengetahuan dan teori yang dimiliki untuk kemudian membuktikan hipotesis yang mereka rumuskan. Setelah melakukan proses hipotesis, guru kemudian membimbing peserta didik untuk menumpulkan berbagai macam sumber bacaan yang berkaitan dengan materi empati, ajaran Islam tentang empati, dalil Al quran maupun hadits yang berkaitan dengan empati ataupun kisah-kisah nabi dan para sahabat yang berkaitan dengan empati.

Sumber bacaan atau literatur sebagai rujukan dapat berupa buku cetak maupun bersumber dari internet. Berkaitan dengan hal ini maka guru perlu mempertimbangkan ketersediaan sumber belajar di perpustakaan sekolah ataupun fasilitas internet yang memadai. Sebaiknya guru memberi tugas kepada peserta didik untuk mempersiapkan berbagai sumber bacaan tersebut pada pertemuan sebelumnya, jika tidak memungkinkan mengadakan pembelajaran di perpustakaan, hal tersebut juga mempertimbangkan kepraktisan alokasi waktu yang tersedia.

\section{d. Step 4. Memahami dan menafsirkan bukti}

Peserta didik memahami dan menafsirkan bukti yang terkumpul untuk menjawab hipotesis. Berdasarkan kajian materi yang telah dilakukan, kemudian guru membimbing peserta didik untuk melakukan analisis dan mengaitkan materi empati berdasarkan ajaran Islam dengan permasalahan yang disajikan.

\section{e. Step 5. Merefleksikan Bukti yang Terkumpul}

Memberikan kesempatan kepada peserta didik untuk merefleksikan bukti-bukti yang terkumpul dengan fenomena sosial yang ada di sekeliling mereka dan bagaimana memberikan alternatif pemecahan masalah sesuai dengan pengetahuan yang telah dimiliki sebelumnya. Pada tahap ini guru membimbing peserta didik untuk merefleksikan pembelajaran yang telah 
dilakukan dan tindakan apa yang dapat dilakukan peserta didik untuk merespon kejadian tersebut sesuai dengan pengetahuan yang dipelajari pada langkah sebelumnya.

\section{f. Step 6. Membuat Laporan Secara Tertulis}

Peserta didik membuat kesimpulan terhadap hasil analisis dan proses refleksi dalam bentuk hasil laporan tertulis secara sederhana. Laporan tertulis disusun secara sistematis berdasarkan pada langkah-langkah sebelumnya.

\section{g. Step 7. Melakukan Presentasi}

Mempresentasikan hasil laporan tertulis. Pada tahap ini guru dapat memilih beberapa hasil pekerjaan peserta didik yang terbaik untuk dipresentasikan di depan kelas. Langkah ini dilakukan dengan tujuan untuk meningkatkan partisipasi aktif peserta didik dalam pembelajaran, memberikan umpan balik secara langsung, memberikan penguatan dan memberikan konfirmasi terhadap pembelajaran yang telah dilakukan.

\section{Kesimpulan}

Lampiran permendikbud no 58 tahun 2014 tentang kurikulum sekolah menengah pertama menjelaskan jika Pendidikan Agama Islam (PAI) dan Budi Pekerti adalah pendidikan yang memberikan pengetahuan dan keterampilan serta membentuk sikap, dan kepribadian peserta didik dalam mengamalkan ajaran agama Islam, sebagai sumber utama nilai-nilai kehidupan bagi manusia dan alam semesta. Sekaligus merupakan landasan pengembangan nilai-nilai karakter bangsa Indonesia.

Implementasi model reflective moral inquiry dalam pembelajaran PAI sangat relevan dengan arah dan tujuan PAI yang menjadikan pengetahuan tentang ajaran agama sebagai sumber utama nilai-nilai kehidupan sekaligus sebagai landasan pengembangan karakter. Dengan pendekatan kontekstual yang bersifat reflective dan self -analitic, model tersebut mengajarkan kepada peserta didik untuk dapat mengimplementasikan pengetahuan agama yang di ajarkan sebagai dasar dalam menyelesaikan berbagai macam permasalahan moral yang terjadi dalam kehidupan sehari-hari. 
Dampak dari model reflective moral inquiry dalam pembelajaran PAI diharapkan dapat memberikan pembelajaran yang bermakna, dimana peserta didik dapat mengkorelasikan pengetahuan agama yang ia miliki sebagai landasan dan sumber nilai dalam kehidupan nyata.

\section{DAFTAR PUSTAKA}

Abdi, Muhammad Iwan. "Contextual Teaching and Learning (CTL) Dalam Pembelajaran PAI." Dinamika Ilmu 11, no. 1 (June 15, 2011). https://doi.org/10.21093/di.v11i1.49.

Budiningsih, Asri. Belajar Dan Pembelajaran. Yogyakarta: Fakultas ilmu pendidikan Uiversitas Negeri Yogyakarta, 2003.

Dewey, John. How We Think. Mineola, N.Y: Dover Publications, 1997.

Guidry, Allen 0. "Character Education Through a Reflective Moral Inquiry: A Revised Model That Answers Old Questions." Journal of Curriculum and Instruction 2, no. 1 (January $2, \quad$ 2008). https://doi.org/10.3776/joci.2008.v2n1p21-37.

- - - "Character Education Through a Reflective Moral Inquiry: A Revised Model That Answers Old Questions." Journal of Curriculum and Instruction 2, no. 1 (January 2, 2008). https://doi.org/10.3776/joci.2008.v2n1p21-37.

Jahja, Yudrik. Psikologi Perkembangan. 3rd ed. Jakarta: Kencana, 2011.

Jordan, Silvia, Martin Messner, and Albrecht Becker. "Reflection and Mindfulness in Organizations: Rationales and Possibilities for Integration." Management Learning 40, no. 4 (September 2009): 465-73. https://doi.org/10.1177/1350507609339687.

Kenneth, Howey R. Contextual Teaching and Learning: Preparing Teacher to Enhance Student Success in and beyond School. washington DC: ERIC Clearinghouse on Teaching and Teacher Education American Association off College for Teacher Education., 2001.

Kuhlthau, Carol Collier, Leslie K. Maniotes, and Ann K. Caspari. Guided Inquiry: Learning in the 21st Century. Westport, Conn: Libraries Unlimited, 2007.

Lewis, Marilyn, and Hayo Reinders. Using Student-Centered Methods with TeacherCentered Students. Pippin Publishing Corporation, 2007.

Moore, Kenneth D. Effective Instructional Strategies: From Theory to Practice. 2nd ed. Thousand Oaks, Calif: Sage Publications, 2009.

Munthe, Bermawy. “Desain Strategi Pembelajaran PAI Di Sekolah” 1 (20`13).

_-_. "Desain Strategi Pembelajaran Pendidikan Agama Islam DI Sekolah." ElWasathiya: Jurnal Studi Agama; Vol 1 No 1 (2013), June 13, 2013. 
http://ejournal.kopertais4.or.id/mataraman/index.php/washatiya/article/ view/1660.

Nuh, Mohammad. Menyemai Kreator Peradaban: Renungan Tentang Pendidikan, Agama, Dan Budaya. Cetakan I. Jakarta: Zaman, 2013.

Rodgers, Carol. "Defining Reflection: Another Look at John Dewey and Reflective Thinking." Teachers College, Columbia University 104 (2002): 842-66.

Ross, Dorene Doerre. "First Steps in Developing A Reflective Approach." Journal of Teacher Education 40, no. 2 (March 1989): 22-30. https://doi.org/10.1177/002248718904000205.

Sanjaya, Wina. Strategi Pembelajaran Berorientasi Standar Proses Pendidikan. Jakarta: Kencana, 2010.

Schunk, Dale H. Learning Theories: An Educational Perspective. 6th ed. Boston: Pearson, 2012.

Suyanto, and Asep Jihad. Menjadi Guru Profesional Strategi Meningkatkan Dan Kualitas Guru Di Ers Global. Erlangga, 2013.

Zeichner, Kenneth M., and Daniel Patrick Liston. Reflective Teaching: An Introduction. Reflective Teaching and the Social Conditions of Schooling. Mahwah, N.J: L. Erlbaum Associates, 1996. 